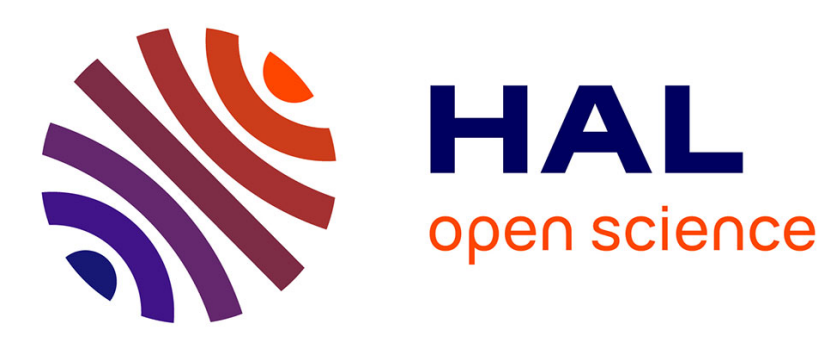

\title{
Impact of cerium oxide nanoparticles shape on their in vitro cellular toxicity
}

Valérie Forest, Lara Leclerc, Jean-François Hochepied, Adeline Trouvé, Gwendoline Sarry, Jérémie Pourchez

\section{- To cite this version:}

Valérie Forest, Lara Leclerc, Jean-François Hochepied, Adeline Trouvé, Gwendoline Sarry, et al.. Impact of cerium oxide nanoparticles shape on their in vitro cellular toxicity. Toxicology in Vitro, 2017, 38, pp.136-141. 10.1016/j.tiv.2016.09.022 . hal-01421912

HAL Id: hal-01421912

https://hal-mines-paristech.archives-ouvertes.fr/hal-01421912

Submitted on 9 Oct 2018

HAL is a multi-disciplinary open access archive for the deposit and dissemination of scientific research documents, whether they are published or not. The documents may come from teaching and research institutions in France or abroad, or from public or private research centers.
L'archive ouverte pluridisciplinaire HAL, est destinée au dépôt et à la diffusion de documents scientifiques de niveau recherche, publiés ou non, émanant des établissements d'enseignement et de recherche français ou étrangers, des laboratoires publics ou privés. 
Impact of cerium oxide nanoparticles shape on their in vitro cellular toxicity

Valérie Forest ${ }^{* a, b, c}$, Lara Leclerc ${ }^{\mathrm{a}, \mathrm{b}, \mathrm{c}}$, Jean-François Hochepied ${ }^{\mathrm{d}, \mathrm{e}}$, Adeline Trouvé ${ }^{\mathrm{d}, \mathrm{e}}$, Gwendoline Sarry ${ }^{\mathrm{a}, \mathrm{b}, \mathrm{c}}$, Jérémie Pourchez ${ }^{\mathrm{a}, \mathrm{b}, \mathrm{c}}$.

${ }^{\text {a }}$ Ecole Nationale Supérieure des Mines de Saint-Etienne, CIS-EMSE, SAINBIOSE, F-42023 Saint Etienne, France.

${ }^{\mathrm{b}}$ INSERM, U1059, F-42023 Saint Etienne, France.

${ }^{\mathrm{c}}$ Université de Lyon, F-69000 Lyon, France.

${ }^{\mathrm{d}}$ MINES ParisTech, PSL Research University, MAT - Centre des matériaux, CNRS UMR 7633, BP 8791003 Evry, France.

${ }^{\text {e }}$ UCP, ENSTA ParisTech, Université Paris-Saclay, 828 bd des Maréchaux, 91762 Palaiseau cedex France.

* Corresponding author: Valérie Forest:

École Nationale Supérieure des Mines de Saint-Etienne

158 cours Fauriel, CS 62362

42023 Saint-Etienne Cedex 2. FRANCE.

Email address: vforest@emse.fr - Telephone number: +33477499776 


\section{Graphical abstract}

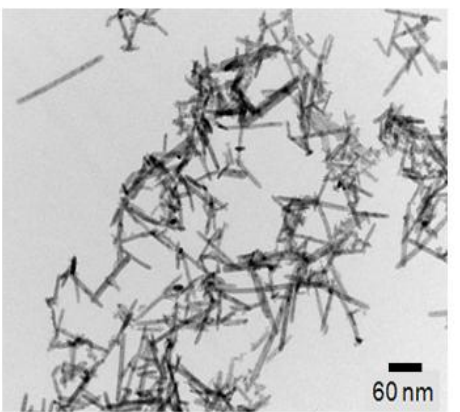

$\operatorname{Rod} \mathrm{CeO}_{2}$ nanoparticles

dic/octahedral

$\mathrm{CeO}_{2}$ nanoparticles

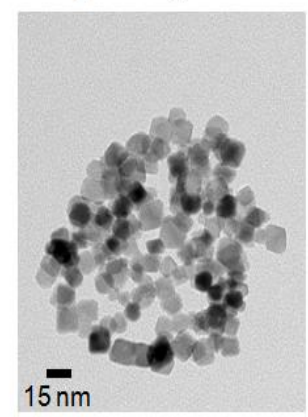

LDH TNF- $\alpha$

release production

++++ Strong impact of $\mathrm{CeO}_{2}$ nanoparticle shape on their in vitro toxicity

$\Rightarrow$ should be carefully taken in

consideration, especially in a "safer by design" context. 


\begin{abstract}
Cerium oxides $\left(\mathrm{CeO}_{2}\right)$ nanoparticles, also referred to as nanoceria, are extensively used with a wide range of applications. However, their impact on human health and on the environment is not fully elucidated. The aim of this study was to investigate the influence of the $\mathrm{CeO}_{2}$ nanoparticles morphology on their in vitro toxicity. $\mathrm{CeO}_{2}$ nanoparticles of similar chemical composition and crystallinity were synthesized, only the shape varied (rods or octahedrons/cubes). Macrophages from the RAW264.7 cell line were exposed to these different samples and the toxicity was evaluated in terms of lactate dehydrogenase (LDH) release, Tumor Necrosis Factor alpha (TNF- $\alpha$ ) production and reactive oxygen species (ROS) generation. Results showed no ROS production, whatever the nanoparticle shape. The LDH release and the TNF- $\alpha$ production were significantly and dose-dependently enhanced by rodlike nanoparticles, whereas they did not vary with cubic/octahedral nanoparticles. In conclusion, a strong impact of $\mathrm{CeO}_{2}$ nanoparticle morphology on their in vitro toxicity was clearly demonstrated, underscoring that nanoceria shape should be carefully taken in consideration, especially in a "safer by design" context.
\end{abstract}

\title{
Key-words
}

Cerium oxide nanoparticles, nanoceria, morphology, toxicity. 


\section{Introduction}

Cerium belongs to the lanthanide elements also known as rare-earth metals. Cerium oxides $\left(\mathrm{CeO}_{2}\right)$ nanoparticles, also referred to as nanoceria, have a wide range of industrial and commercial applications: mainly as fuel additives but also as UV protection (in paints or sunscreens), catalysts, polishing agents, gas sensors, etc. (Courbiere et al., 2013; De Marzi et al., 2013; Demokritou et al., 2013; Fisichella et al., 2014; Lin et al., 2006; Lord et al., 2012; Mittal and Pandey, 2014; Peng et al., 2014; Pulido-Reyes et al., 2015; Xia et al., 2008). Recently, they also experienced growing attention for biomedical applications as they were found to exhibit protecting effects against cellular damage induced by toxicants, radiation or in pathological situations such as cardiac or brain ischemia/reperfusion, certain neurological disorders or retinal neurodegeneration (Culcasi et al., 2012; Mittal and Pandey, 2014; PulidoReyes et al., 2015). Their potential to behave as anticancer agent has also been explored (Gao et al., 2014; Pulido-Reyes et al., 2015).

Due to this large use, the risk of $\mathrm{CeO}_{2}$ nanoparticles release in the environment and exposure to humans (especially through inhalation) are potentially growing while their impact on human health and on the ecosystems is still not fully elucidated. This observation has led the Organization for Economic Co-operation and Development (OECD) to classify since 2010 these nanoparticles among the top priority materials for toxicological evaluations (Courbiere et al., 2013; Mittal and Pandey, 2014; OECD Environment, Health and Safety Publications et al., 2010; Peng et al., 2014).

Indeed, the toxicity of nanoceria remains controversial as conflicting results have been reported in the literature. It is generally admitted that cerium oxides have a low toxicity profile (Urner et al., 2014) and it has been shown in different models that although internalized by cells $\mathrm{CeO}_{2}$ nanoparticles do not trigger inflammation or cytotoxicity (Fisichella et al., 2014; Franchi et al., 2015; Xia et al., 2008). But evidence that cell death can 
be induced by $\mathrm{CeO}_{2}$ nanoparticles was also given by Pešić et al. (Pešić et al., 2015). Similarly, regarding oxidative stress, some studies have reported that cerium oxide nanoparticles can be either pro-oxidative (Pešić et al., 2015) or on the contrary can exhibit anti-oxidant properties (Lord et al., 2012; Mittal and Pandey, 2014; Rosenkranz et al., 2012; Schubert et al., 2006; Xia et al., 2008). Nanoceria can exert a pro-oxidative effect by producing reactive oxygen species (ROS) responsible for cell damages that can themselves potentially lead to cell death, and also by inducing changes in the intracellular redox status (Pešić et al., 2015). Thus, some studies have shown that nanoceria can induce oxidative stress either in vitro or in vivo (Pešić et al., 2015). On the other hand, cerium oxide nanoparticles were found to behave as direct antioxidants by acting as free radical scavengers (especially by interacting with hydroxyl radical $\left[\mathrm{OH}^{\circ}\right]$, superoxide radical $\left[\mathrm{O}_{2}{ }^{-}\right]$and hydrogen peroxide $\left[\mathrm{H}_{2} \mathrm{O}_{2}\right]$ ) and therefore protecting cells from death due to oxidative stress (Lord et al., 2012; Mittal and Pandey, 2014; Rosenkranz et al., 2012; Schubert et al., 2006; Xia et al., 2008).

Two main reasons can be evoked to explain these discrepancies. First, no standardized assays exist, making the comparison impossible among the different studies from the literature and therefore making it really difficult to draw firm conclusion on nanoceria toxic potential. Second and most importantly, it seems that numerous parameters are involved in $\mathrm{CeO}_{2}$ nanoparticle toxicity: factors from the environment but also the intrinsic physico-chemical features of nanoparticles. Regarding the environmental context, $\mathrm{pH}$ seems to play a key role as it can drive either the anti-oxidant or pro-oxidant activity of nanoceria (Gao et al., 2014; Lord et al., 2012; Mittal and Pandey, 2014; Pešić et al., 2015; Rosenkranz et al., 2012). Indeed, in a neutral $\mathrm{pH}$ environment, $\mathrm{CeO}_{2}$ nanoparticles are cytoprotective and act as antioxidants whereas at acidic $\mathrm{pH}$ they behave as oxidases leading to cytotoxic effects. This might be a reason of different influence of nanoceria on normal and cancer cells as these latter are characterized by an acidic $\mathrm{pH}$ environment. This leads to another environmental parameter 
that could greatly influence the response to nanoceria: the cell type in which biological assays are carried out. This was clearly demonstrated by different studies (Lanone et al., 2009; Pešić et al., 2015; Rosenkranz et al., 2012) where the biological behavior of cells from various cell lines following incubation with $\mathrm{CeO}_{2}$ nanoparticles were compared. All these studies concluded to a difference of sensitivity between cell types (both between normal cells and cancer cells but also among the different cell lines).

Nanoceria toxicity can also rely on intrinsic nanoparticle physico-chemical characteristics such as surface chemistry, size, shape, dispersion state (Fisichella et al., 2014), the synthesis process (Lord et al., 2012), etc, but more particularly the dual oxidation state of $\mathrm{CeO}_{2}$ nanoparticles. It is well documented that cerium can exist as $\mathrm{Ce}^{3+}$ or $\mathrm{Ce}^{4+}$, this particular configuration allows the unique reduction/oxidation behavior of nanoceria which is responsible for their antioxidant properties (De Marzi et al., 2013; Mittal and Pandey, 2014; Pešić et al., 2015; Pulido-Reyes et al., 2015; Rosenkranz et al., 2012).

Among the different nanoparticle physico-chemical features that could be involved in the nanoceria in vitro toxicity, we focused our attention on the influence of the morphology. Therefore the aim of the present study was to investigate if a relationship existed between the cerium oxide nanoparticles shape and the biological response they induced in a model of macrophages in the perspective of designing safer nanoparticles. Several methods are eligible to produce nanoceria with various and controlled shapes, but the point is to change the shape without risking to change other physico-chemical characteristics that could have an impact on toxicity, for instance by using additives that could be difficult to wash thoroughly and could induce toxicity at trace levels, or by choosing very different methods for each shape. So the ideal case consists in selecting a protocol allowing shape tuning just by changing continuously some physico-chemical conditions as temperature, $\mathrm{pH}$ or reaction time, keeping the same chemical reactants. After a literature survey, we considered that protocols published by Florea 
et al. (Florea et al., 2013) were the most relevant. Consequently, the obtained nanoparticles were of identical chemical composition and crystallinity, only the morphology varied (rods or octahedrons/cubes). Macrophages from the RAW264.7 cell line were exposed to these different samples and the in vitro toxicity was evaluated in terms of lactate dehydrogenase $(\mathrm{LDH})$ release, Tumor Necrosis Factor alpha (TNF- $\alpha$ ) production and reactive oxygen species generation.

\section{Materials and methods}

Cerium oxide nanoparticle synthesis

The protocols were selected from Florea's article and $\mathrm{PhD}$ thesis (Florea et al., 2013). Basically, after mixing at room temperature a solution of $\mathrm{Ce}(\mathrm{III})$ salt with the basic solution (soda/ammonia), the precipitate was heated by microwave irradiation at different temperatures and times. Shape tuning (octahedrons, cubes, rods) was expected depending on the conditions. All syntheses were performed with a 10 minutes heating ramp between room temperature and the desired temperature. The experimental conditions are summarized in Table 1. The given time corresponds to the plateau at the desired temperature. Cooling was relatively fast (a few minutes). In one set of conditions, we compared 2 microwave ovens: Monowave (M) and Synthos (S). After cooling, samples were washed 3 times by centrifugations and redispersed in water. 
Table 1 - Experimental conditions for the cerium oxide nanoparticle synthesis.

C: concentration, V: volume, T: temperature, t: time, M: Monowave, S: Synthos.

\begin{tabular}{|c|c|c|c|c|c|c|c|c|}
\hline Sample & $\begin{array}{l}\mathrm{C}(\mathrm{Ce}) \\
\mathrm{mol} / \mathrm{L}\end{array}$ & $\begin{array}{c}\mathrm{V}(\mathrm{Ce}) \\
\mathrm{mL}\end{array}$ & $\begin{array}{c}\mathrm{C}(\mathrm{NaOH}) \\
\mathrm{mol} / \mathrm{L}\end{array}$ & $\begin{array}{c}\mathrm{V}(\mathrm{NaOH}) \\
\mathrm{mL}\end{array}$ & $\begin{array}{c}\mathrm{V}(\mathrm{NH} 3 \\
28 \%) \\
\mathrm{mL}\end{array}$ & $\mathrm{T}\left({ }^{\circ} \mathrm{C}\right)$ & $\mathrm{t}(\min )$ & Microwave \\
\hline $\mathrm{CeO}_{2}-\mathrm{R} 1$ & $3.8 \times 10^{-3}$ & 50 & 12 & 20 & 5.4 & 120 & 25 & $\mathrm{M}$ \\
\hline $\mathrm{CeO}_{2}-\mathrm{R} 2$ & $3.8 \times 10^{-3}$ & 50 & 12 & 20 & 5.4 & 180 & 45 & $\mathrm{M}$ \\
\hline $\mathrm{CeO}_{2}-\mathrm{R} 3$ & 0.1 & 19 & 12 & 20 & 5.4 & 180 & 45 & $\mathrm{M}$ \\
\hline $\mathrm{CeO}_{2}-\mathrm{O} 1$ & 0.1 & 24 & I & 0 & 1.4 & 180 & 60 & $\mathrm{M}$ \\
\hline $\mathrm{CeO}_{2}-\mathrm{O} 2$ & 0.1 & 19 & 12 & 20 & 5.4 & 180 & 45 & $S$ \\
\hline
\end{tabular}

\section{Physico-chemical characterization}

Size and shape of particles were examined by transmission electron microscopy (TEM) with a TECNAI $20 \mathrm{~F}$ microscope operating at $200 \mathrm{kV}$. For cubic or octahedral particles, around 150 particles were measured manually using ImageJ software. Due to their non spherical shape, it was chosen to measure the biggest dimension. For rod-like particles, diameter and length distributions were measured counting around 150 particles. The mode (most represented class) was also determined in each case.

Nitrogen $\left(\mathrm{N}_{2}\right)$ adsorption/desorption isotherms were measured at $77 \mathrm{~K}$ using a Micromeritics ASAP 2010 Analyser. After degassing under vacuum at $80^{\circ} \mathrm{C}$, the specific surface area of the powders was determined by applying the Brunauer Emmet Teller (BET) model method on the desorption branch. The equivalent spherical particle diameter was estimated with the following formula $D=6000 /\left(\rho \times S_{B E T}\right)$, where $D_{B E T}(n m)$ is the average diameter of the particles, $\mathrm{S}_{\mathrm{BET}}\left(\mathrm{m}^{2} \cdot \mathrm{g}^{-1}\right)$ the specific area and $\rho\left(\mathrm{g} . \mathrm{cm}^{-3}\right)$ the theoretical density of the powder. For rods, neglecting the tip surface as compared to the lateral surface, we used the formula $d=$ $4000 /\left(\rho \times \mathrm{S}_{\mathrm{BET}}\right)$ with d diameter of the rods. 
In vitro toxicity assays

Cell culture - The RAW 264.7 cell line derived from mice peritoneal macrophages transformed by the Abelson murine leukemia virus and was provided by ATCC Cell Biology Collection (Promochem, LGC, Molsheim, France). Cells were cultured in Dulbecco Modified Eagle Medium (DMEM) complemented with $10 \%$ of fetal calf serum and $1 \%$ of penicillinstreptomycin (called DMEMc) at $37^{\circ} \mathrm{C}$ under a 5\% carbon dioxide humidified atmosphere.

Nanoparticle/cell contacts - Cells were seeded in 96-well-plates $(100000$ cells in $50 \mu \mathrm{L}$ of medium per well) and were allowed to adhere over night. Nanoparticles were diluted in cell culture medium to reach the following final concentrations: $15,30,60$ and $120 \mu \mathrm{g} / \mathrm{mL}$. Nanoparticles were added to cells and further incubated for $24 \mathrm{~h}$.

Lactate dehydrogenase $(\mathrm{LDH})$ release - To evaluate cell membrane integrity, the cellular release in the supernatant of cytoplasmic lactate dehydrogenase was assessed using the CytoTox-96 ${ }^{\mathrm{TM}}$ Homogeneous Membrane Integrity Assay (Promega, Charbonnières-les-Bains, France) according to the manufacturer's instructions. The optical density of the samples was determined using a microplate reader (Multiskan RC; Thermolabsystems, Helsinki, Finland) set to $450 \mathrm{~nm}$. Three independent experiments were performed, each in quadruplicate and the activity of the released LDH was reported to that of negative control cells (incubated without nanoparticles). A positive control consisted in the maximal cellular LDH released after cells lysis.

TNF- $\alpha$ production - After incubation with nanoparticles, the production of TNF- $\alpha$ was assessed in the supernatant using a commercial ELISA Kit (Quantikine ${ }^{\circ}$ Mouse TNF- $\alpha$ Immunoassay; R\&D Systems, Lille, France) according to the manufacturer's instructions. The 
optical density of each sample was determined using a microplate reader (Multiskan RC; Thermolabsystems, Helsinki, Finland) set to $450 \mathrm{~nm}$. A standard curve was established and results were expressed in picograms of TNF- $\alpha$ per milliliter of supernatant. Three independent experiments were performed, each in quadruplicate and the production of TNF- $\alpha$ was reported to that of control cells (incubated without nanoparticles).

Reactive oxygen species (ROS) production - A large array of ROS activity can be assessed with the OxiSelect ${ }^{\mathrm{TM}}$ ROS Assay Kit (Euromedex, Mundolsheim, France). The assay uses the conversion of a non-fluorescent substrate, 2.7'-dichlorodihydrofluorescein diacetate that can easily diffuse through cell membranes and be converted into a fluorogenic molecule $2^{\prime} .7^{\prime}-$ dichlorodihydrofluorescein (DCF) in presence of ROS: fluorescence amount is directly related to ROS level. Fluorescence was detected using a Fluoroskan Ascent fluorometer (Ex: $480 \mathrm{~nm}$, Em: $530 \mathrm{~nm}$, Thermolabsystems) after a $90 \mathrm{~min}$ incubation of cells with the nanoparticles. A positive control was included incubating cells with $\mathrm{H}_{2} \mathrm{O}_{2}(1 \mathrm{mM})$. Three independent experiments were performed, each in quadruplicate and the generation of ROS was reported to that of the negative control (cells incubated without nanoparticles).

Statistical analysis - Analyses and graphics were performed on Prism 6.0c software (GraphPad, San Diego, CA). Significance was established with two-ways ANOVA tests ( $\mathrm{p}<$ $0.05)$ and Tukey post-tests $(* * *: \mathrm{P}<0.001$ and $* *: \mathrm{P}<0.01)$. Each data point represents the mean of at least three independent experiments and is presented with the arithmetic standard error of the means $( \pm$ SEM). 


\section{Results}

Physico-chemical characterization

The physico-chemical features of the different nanoceria used in this study are reported in Table 2.

Table 2 - Physico-chemical features of the different nanoceria.

\begin{tabular}{|c|c|c|c|c|c|c|c|c|}
\hline Nanoparticle & Composition & $\begin{array}{c}\text { Particle size (nm) } \\
\text { TEM }\end{array}$ & Shape & Mode & BET & $\begin{array}{c}\text { Specific } \\
\text { surface } \\
\text { area } \\
\left(\mathrm{m}^{2} / \mathrm{g}\right)\end{array}$ & $\begin{array}{c}\text { Agglomeration/ } \\
\text { aggregation } \\
\text { state }\end{array}$ & $\begin{array}{c}\text { Zeta } \\
\text { potential } \\
\text { pH7 } \\
(\mathrm{mV})\end{array}$ \\
\hline $\mathrm{CeO}_{2}-\mathrm{R} 1$ & $\mathrm{CeO}_{2}$ & $5.5( \pm 1.3) \times 44( \pm 19)$ & Rod & $4.5-5.5$ & 3.5 & 151 & Low & $-26( \pm 11)$ \\
\hline $\mathrm{CeO}_{2}-\mathrm{R} 2$ & $\mathrm{CeO}_{2}$ & $6.2( \pm 1.1) \times 45( \pm 14)$ & Rod & $6.2-7.3$ & 8.5 & 61 & Low & $-35( \pm 14)$ \\
\hline $\mathrm{CeO}_{2}-\mathrm{R} 3$ & $\mathrm{CeO}_{2}$ & $8.1( \pm 1.8) \times 70( \pm 34)$ & Rod & $6.8-8.3$ & 14 & 37 & Low & $-31( \pm 7)$ \\
\hline $\mathrm{CeO}_{2}-\mathrm{O} 1$ & $\mathrm{CeO}_{2}$ & $11.3( \pm 2.8)$ & Octahedron & $10.0-12.0$ & 13 & 60 & Low & $-17( \pm 5)$ \\
\hline $\mathrm{CeO}_{2}-\mathrm{O} 2$ & $\mathrm{CeO}_{2}$ & $16.2( \pm 3.6)$ & Cube/octahedron & $12.6-15.0$ & 13 & 61 & Low & $+9( \pm 6)$ \\
\hline
\end{tabular}

As illustrated by Figure 1, the different morphologies of the nanoceria could be clearly distinguished using transmission electron microscopy. Samples $\mathrm{CeO}_{2}-\mathrm{R} 1, \mathrm{CeO}_{2}-\mathrm{R} 2$ and $\mathrm{CeO}_{2}-\mathrm{R} 3$ are nanorods with increasing dimensions. $\mathrm{CeO}_{2}-\mathrm{R} 1$ are thin and short rods, with diameters close to $5 \mathrm{~nm}$ and lengths close to $40 \mathrm{~nm}$. $\mathrm{CeO}_{2}-\mathrm{R} 2$ samples have more or less the same length as $\mathrm{CeO}_{2}-\mathrm{R} 1$, but are slightly thicker rods with diameters around $6 \mathrm{~nm}$, and finally $\mathrm{CeO}_{2}-\mathrm{R} 3$ are the biggest rods with diameters close to $8 \mathrm{~nm}$ and much longer and polydisperse, around $70 \mathrm{~nm}$. BET equivalent diameters exhibit a much sharper variation than expected by TEM. This may be due to size and shape polydispersity, and the fact that rods could be more or less flat, rather than cylindrical. According to synthesis protocols, $\mathrm{CeO}_{2}-\mathrm{R} 3$ was not expected to be rod-like but cubic, in fact the same protocol performed with the Synthos apparatus instead of the monowave produced isotropic particles $\left(\mathrm{CeO}_{2}-\mathrm{O} 2\right)$, but not purely cubic ones, rather a mixture of cubes, octahedrons and cuboctahedrons. This difference 
between $\mathrm{CeO}_{2}-\mathrm{R} 3$ and $\mathrm{CeO}_{2}-\mathrm{O} 2$ is probably due to the sensitiveness of the system to temperature and a better temperature probe for the Synthos, but this discussion is beyond the scope of the article. So at the end, we have 2 families, rods and isotropic particles that can be compared. Interestingly, $\mathrm{CeO}_{2}-\mathrm{R} 2$ and $\mathrm{CeO}_{2}-\mathrm{O} 1 / \mathrm{O} 2$ exhibit the same specific surface area, but a very different shape, which is very useful to establish if effects are only due to shape. We also observed that agglomeration seems rather weak for all samples. As far as zeta potential in water at $\mathrm{pH} 7$ is concerned, values obtained for anisotropic particles are close to $30 \mathrm{mV}$ but with a high standard deviation (especially for $\mathrm{CeO}_{2}-\mathrm{R} 1$ and $\mathrm{CeO}_{2}-\mathrm{R} 2$ ) whereas the zeta potential of isotropic particles is less negative for $\mathrm{CeO}_{2}-\mathrm{O} 1$ and slightly positive for $\mathrm{CeO}_{2}-\mathrm{O} 2$.

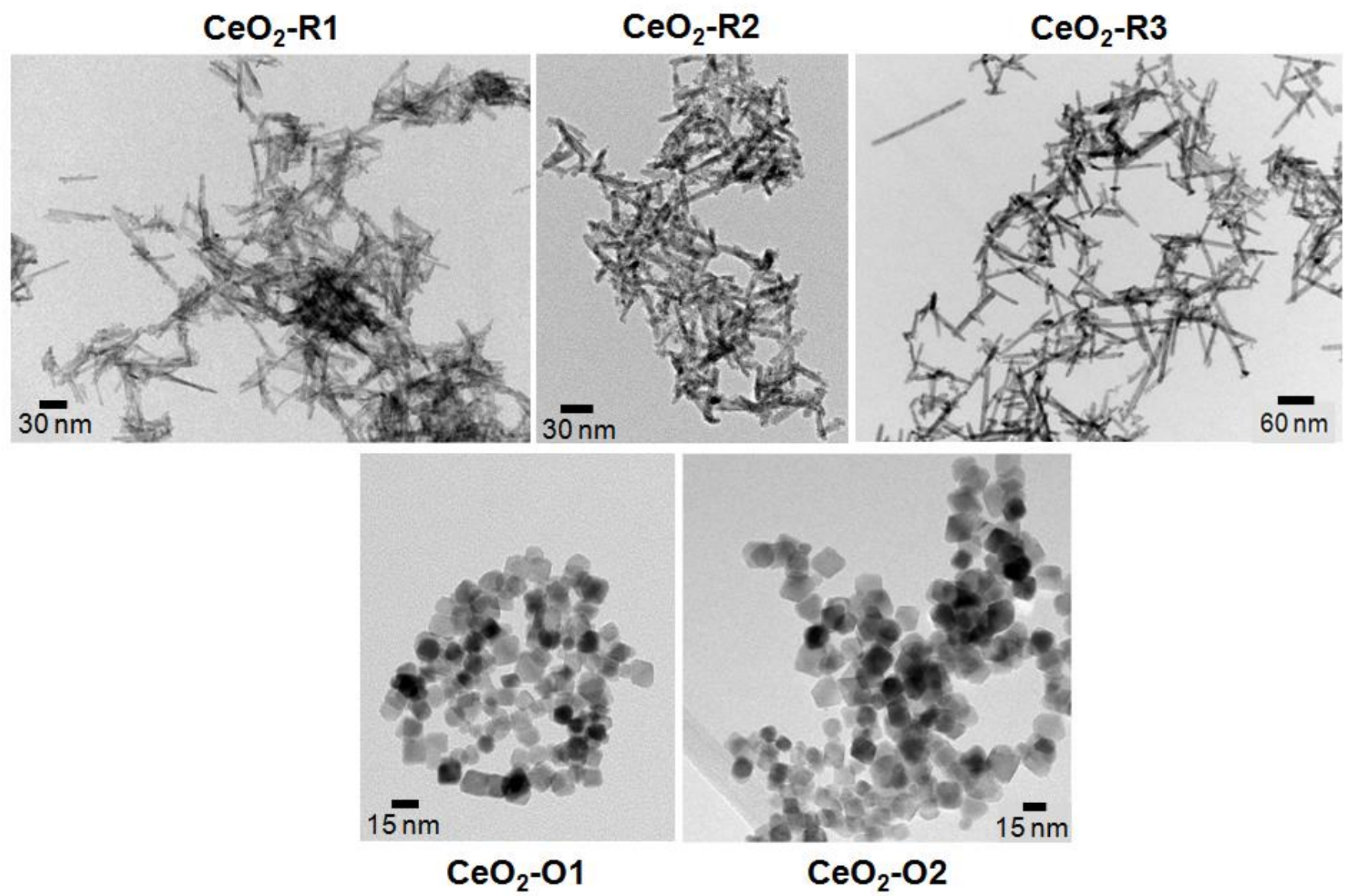

Figure 1 - Transmission electron microscope images of the different nanoceria particles $(\mathrm{R}=$ Rods, $\mathrm{O}=$ Octahedrons). 
In vitro toxicity assays

Figure 2 reports the loss of cell membrane integrity as evaluated by the LDH released from cells after incubation with the different $\mathrm{CeO}_{2}$ nanoparticles. It clearly appeared that rod particles induced a significant and dose-dependent LDH release whereas that triggered by octahedron particles did not differ from that observed for control cells.

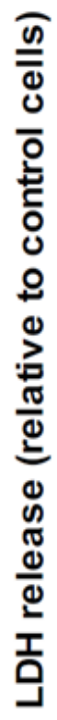

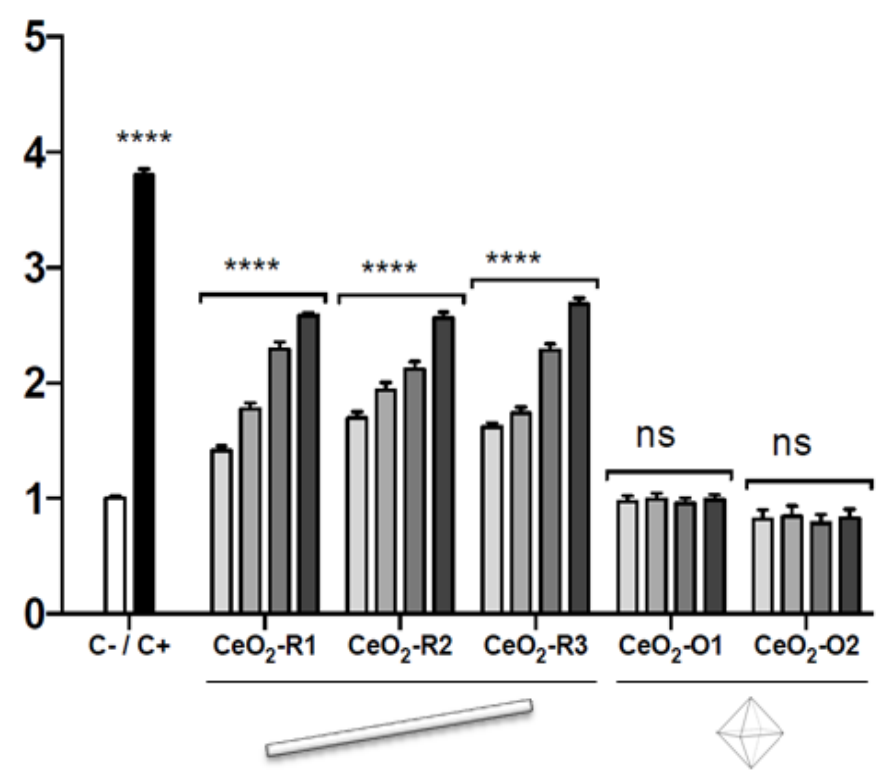

$\square 15 \mu \mathrm{g} / \mathrm{mL}$

$\square 30 \mu \mathrm{g} / \mathrm{mL}$

$\square 60 \mu \mathrm{g} / \mathrm{mL}$

$\square 120 \mu \mathrm{g} / \mathrm{mL}$

C- Negative control (cells without nanoparticles)

C+ Positive control (cell lysis)

Figure 2 - Loss of cell membrane integrity assessed by LDH released in the cell culture supernatant after incubation with the different types of nanoceria. Results are expressed relative to control cells (incubated without nanoparticles). $* * * * \mathrm{p}<0.0001$ as determined by the Tukey post-test.

As illustrated by Figure 3, the production of TNF- $\alpha$ was significantly and dose-dependently enhanced by rod nanoparticles compared to control cells while the other shape of nanoceria did not induce a significant variation in the expression of this pro-inflammatory cytokine. 


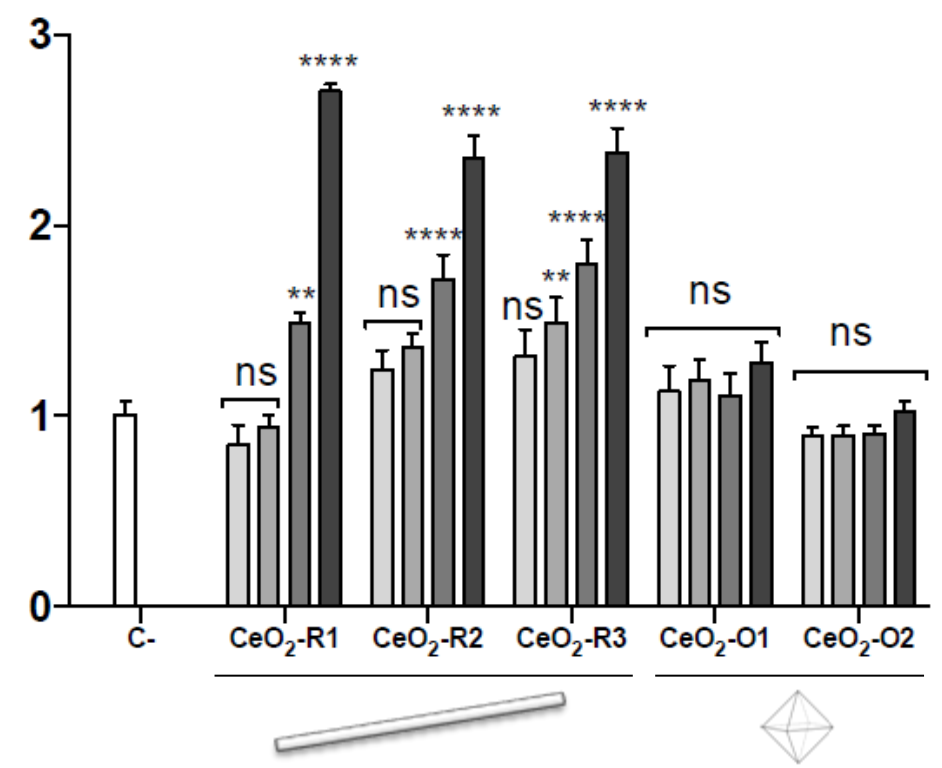

$\square 15 \mu \mathrm{g} / \mathrm{mL}$

$\square 30 \mu \mathrm{g} / \mathrm{mL}$

$\square 60 \mu \mathrm{g} / \mathrm{mL}$

$\square 120 \mu \mathrm{g} / \mathrm{mL}$

C- Negative control (cells without nanoparticles)

Figure 3 - TNF- $\alpha$ production measured after a $24 \mathrm{~h}$ incubation with different nanoceria types.

Results are expressed relative to control cells (incubated without nanoparticles). ${ }^{*} \mathrm{p}<0.01$ and $* * * * \mathrm{p}<0.0001$ as determined by the Tukey post-test.

Oxidative stress was evaluated by the assessment of the amount of ROS produced relative to control cells (incubated without nanoparticles). As shown by Figure 4, no significant ROS production was observed, whatever the type or concentration of nanoparticles. 

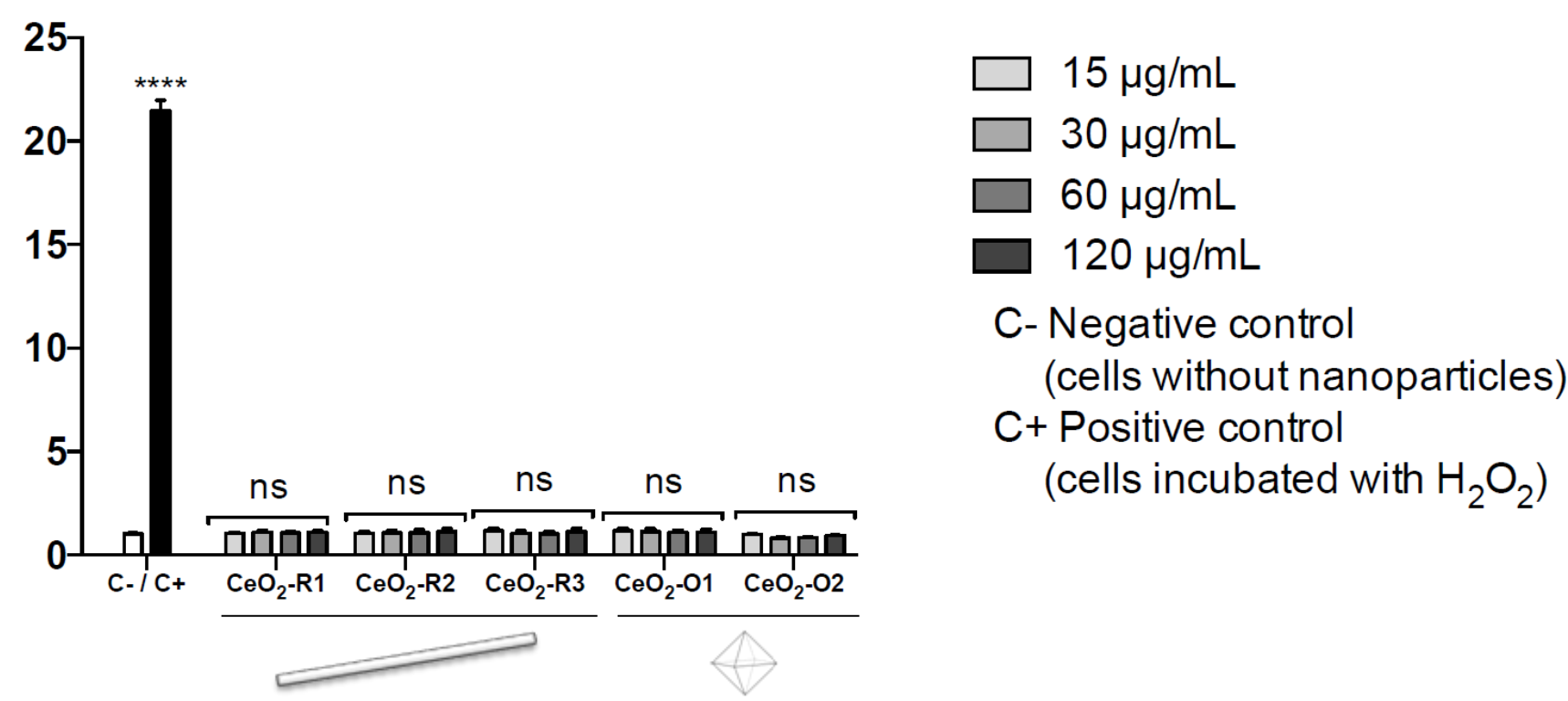

Figure 4 - ROS production assessed 90 min after incubation with the different nanoceria.

Results are expressed relative to control cells (incubated without nanoparticles). **** $\mathrm{p}<0.0001$ as determined by the Tukey post-test.

\section{Discussion}

Nanoceria toxicity remains controversial and data are still missing to firmly conclude on this issue. Among the numerous parameters that could be involved in the nanoCeO $\mathrm{C}_{2}$ toxicity we have chosen to investigate more particularly the impact of the nanoparticle morphology. For that purpose we used a synthesis mode allowing producing different types of particles of wellcontrolled physicochemical features, varying only in terms of shape (rod versus cube/octahedron). The subsequent study of the biological activity induced in macrophages after incubation with the different nanoceria showed that the extracellular release of LDH (Figure 2) and the production of the pro-inflammatory cytokine TNF- $\alpha$ (Figure 3) exhibited similar profiles. Compared to what was observed in control cells, they were significantly and dose-dependently enhanced by rod-like nanoparticles, whereas they did not vary with 
cubic/octahedral nanoparticles. These results clearly argue for a morphological effect of nanoCeO $\mathrm{C}_{2}$. It is also noteworthy to mention that no size effect was observed among the rod nanoparticles as the $\mathrm{LDH}$ release and TNF- $\alpha$ levels were similar between $\mathrm{CeO}_{2}-\mathrm{R} 1, \mathrm{CeO}_{2}-\mathrm{R} 2$ and $\mathrm{CeO}_{2}-\mathrm{R} 3$ which greatly vary in size $\left(\mathrm{CeO}_{2}-\mathrm{R} 3\right.$ rods are almost two times longer than $\mathrm{CeO}_{2}-\mathrm{R} 1$ and $\mathrm{CeO}_{2}-\mathrm{R} 2$, Table 2). Also, we did not observe any correlation between the nanoceria zeta potential and their toxicity. Indeed, the LDH release and TNF- $\alpha$ production triggered by $\mathrm{CeO}_{2}-\mathrm{O} 1$ and $\mathrm{CeO}_{2}-\mathrm{O} 2$ were similar whereas they exhibited a very different zeta potential (-17 and $+9 \mathrm{mV}$ respectively). This remark also applies to the rods even if the difference between their zeta potential was lower (Table 2). This strengthens our previous conclusion of the impact of the nanoceria shape (and not their charge) on their toxicity. Finally, we also showed that nanoceria did not induce any ROS production, whatever their morphology (Figure 4).

These results are only partly consistent with the literature. For instance, regarding the production of ROS, as we did, Xia et al. (Xia et al., 2008) and Urner et al. (Urner et al., 2014) reported that nanoceria did not trigger the production of ROS. On the contrary, Mittal et al. (Mittal and Pandey, 2014) and Lin et al. (Lin et al., 2006) found that nanoCeO $\mathrm{C}_{2}$ were able to induce a significant oxidative stress. Another discrepancy with these same studies regards the cytotoxicty induced. Indeed, Mittal et al. and Lin et al. (Lin et al., 2006; Mittal and Pandey, 2014), observed that nanoceria reduced cell viability, whereas Xia et al. considered it as non toxic. We were in a more nuanced position as we reported that toxicity depends on the morphology as it was significantly enhanced by rod-like nanoparticles but not by cube or octahedron-like nanoparticles. But even more interesting is the comparison with results from Wang et al. paper (Wang et al., 2015) which study design was quite similar to ours. Although they used another cell type (human hepatocellular carcinoma cells, HepG2), they compared the toxicity of three kinds of nanoCeO $\mathrm{O}_{2}$ with different morphologies (cube-, octahedron-, and 
rod-like), using similar ranges of nanoceria concentrations as we did. However, unlike us, they showed that all three types of nanoparticles caused cytotoxicity. They further reported that the toxicity of cube-like nanoCeO $\mathrm{C}_{2}$ was the highest, that of the rod-like was the lowest and that of the octahedron-like was intermediate. They linked this toxicity level to the specific surface area as they observed that a smaller surface area was correlated with a higher cytotoxicity.

The comparison of these different studies illustrates how difficult it is to reach firm conclusions on the nanoceria toxicity. This could be partly explained by the fact that the biological response often depends on the cellular context, especially the $\mathrm{pH}$ (Franchi et al., 2015) and the cell type. The cell type-specific response to particle exposure has already been well established in different models. For instance, Lanone et al. (Lanone et al., 2009) evaluated the toxic effect of 24 nanoparticles, including nanoceria, of similar equivalent spherical diameter and various elemental compositions on two human pulmonary cell lines: A549 and THP-1. Results clearly highlighted the difference of sensitivity between cell types. Similarly, Pešić et al. (Pešić et al., 2015) compared the ROS production induced by nanoCeO $\mathrm{O}_{2}$ in human normal and cancer cell lines. Different responses were observed underlining the selectivity towards human cancer cells. In another model, it was also demonstrated that remarkably more ROS were formed in alveolar macrophages compared to alveolar epithelial cells (Urner et al., 2014). Regarding the protective effects of nanoCeO ${ }_{2}$, it was demonstrated that they could protect cells from harmful effects of radiation and oxidative stress, although this protection was cell type specific (Mittal and Pandey, 2014). Also, nanoCeO $\mathrm{O}_{2}$ showed no toxic effect on normal breast epithelial cells and only a slight effect on breast cancer cells, but were able to protect the normal epithelial cells from radiation while in contrast no such protection was observed for the breast cancer cells (Rosenkranz et al., 2012). 
Another reason explaining why it is so challenging to conclude on nanoceria toxicity is that the underlying mechanisms are particularly complex to investigate. This is especially true for ROS that are unstable and highly reactive species. In this case, the kinetics aspect is of paramount importance and has to be taken into account to determine the optimal detection window. Thus, it has been reported that nanoCeO $\mathrm{O}_{2}$ were able to produce $\mathrm{ROS}$ in a concentration and time dependent manner up to 6 hours (Mittal and Pandey, 2014). But level of ROS was found to be decreased at 24 hours. This may be either due to the increase in amount of cell death or generation of ROS stabilized after a certain time period. Furthermore, a production of ROS can be compensated or masked either by the scavenger activity of nanoCeO $\mathrm{C}_{2}$ or by the cell antioxidant defense system. This is why a complete and thorough study should be undertaken to better understand the oxidative stress mechanism induced by nanoCeO $\mathrm{C}_{2}$. Especially the variation of the antioxidant enzymes level such as the superoxide dismutase (SOD), glutathione (GSH) and catalase should be studied.

It should also be mentioned that care must be taken when concluding on the nanoceria toxicity only on the basis of in vitro experiments. Indeed, although many in vitro studies have concluded that nanoCeO${ }_{2}$ can be regarded as relatively safe nanoparticles, in vivo models allowed underscoring cytotoxicity and inflammation, as well as potential fibrogenicity (Demokritou et al., 2013). For example, it was reported that after oral or intraperitoneal administration of nanoCeO $\mathrm{C}_{2}$ to $\mathrm{CD}-1$ mouse, even if no lethal effect occurred, nanoCeO $\mathrm{C}_{2}$ could induce inflammation status, revealed by cellular, toxicological, and ultrastructural observations (Poma et al., 2014). Similarly, intratracheal instillation of $\mathrm{CeO}_{2}$ nanoparticles in Sprague-Dawley rats was found to result in liver damage (Nalabotu et al., 2011). Finally, Pulido-Reyes et al. (Pulido-Reyes et al., 2015) studied the effect of five different nanoCeO2 on an aquatic microorganism. They concluded that neither shape, concentration, synthesis 
method, surface charge, nor nominal size had any influence in the observed biological activity. Discrepancies between in vitro and in vivo toxicity evaluations may be attributed to particle transformations in the microenvironments of cell culture media enriched with serum proteins versus the alveolar lining fluid of the animal lung (Demokritou et al., 2013). Nanoparticles suspended in physiological media may experience agglomeration and the formation of a protein corona on the particle surface, and these transformations may have a strong impact on subsequent cell/nanoparticle interactions (Forest et al., 2015). Therefore widely used in vitro toxicity assays, such as LDH and MTT assays, may not be predictive of toxicological outcomes observed in vivo. Consequently, further investigations are required.

\section{Conclusion}

In the present paper, we clearly demonstrated an impact of cerium oxide nanoparticle morphology on their in vitro toxicity. Indeed, unlike cubic/octahedral nanoparticles, rod-like nanoparticles significantly and dose-dependently enhanced pro-inflammatory and cytotoxicity responses. Although other complementary studies are needed, this strongly argues for the fact that the shape of the nanoceria is an aspect that should not be neglected, especially in a "safer by design" context.

\section{Acknowledgements}

The authors would like to acknowledge the funding from Institut Mines Telecom, ROQSTAR grant.

\section{References}

Courbiere, B., Auffan, M., Rollais, R., Tassistro, V., Bonnefoy, A., Botta, A., Rose, J., Orsière, T., Perrin, J., 2013. Ultrastructural Interactions and Genotoxicity Assay of Cerium 
Dioxide Nanoparticles on Mouse Oocytes. Int. J. Mol. Sci. 14, 21613-21628. doi:10.3390/ijms 141121613

Culcasi, M., Benameur, L., Mercier, A., Lucchesi, C., Rahmouni, H., Asteian, A., Casano, G., Botta, A., Kovacic, H., Pietri, S., 2012. EPR spin trapping evaluation of ROS production in human fibroblasts exposed to cerium oxide nanoparticles: evidence for NADPH oxidase and mitochondrial stimulation. Chem. Biol. Interact. 199, 161-176. doi:10.1016/j.cbi.2012.08.007

De Marzi, L., Monaco, A., De Lapuente, J., Ramos, D., Borras, M., Di Gioacchino, M., Santucci, S., Poma, A., 2013. Cytotoxicity and Genotoxicity of Ceria Nanoparticles on Different Cell Lines in Vitro. Int. J. Mol. Sci. 14, 3065-3077. doi:10.3390/ijms14023065

Demokritou, P., Gass, S., Pyrgiotakis, G., Cohen, J.M., Goldsmith, W., McKinney, W., Frazer, D., Ma, J., Schwegler-Berry, D., Brain, J., Castranova, V., 2013. An in vivo and in vitro toxicological characterisation of realistic nanoscale $\mathrm{CeO}_{2}$ inhalation exposures. Nanotoxicology 7, 1338-1350. doi:10.3109/17435390.2012.739665

Fisichella, M., Berenguer, F., Steinmetz, G., Auffan, M., Rose, J., Prat, O., 2014. Toxicity evaluation of manufactured $\mathrm{CeO} 2$ nanoparticles before and after alteration: combined physicochemical and whole-genome expression analysis in Caco-2 cells. BMC Genomics 15, 700. doi:10.1186/1471-2164-15-700

Florea, I., Feral-Martin, C., Majimel, J., Ihiawakrim, D., Hirlimann, C., Ersen, O., 2013. Three-Dimensional Tomographic Analyses of $\mathrm{CeO} 2$ Nanoparticles. Cryst. Growth Des. 13, 1110-1121. doi:10.1021/cg301445h

Forest, V., Cottier, M., Pourchez, J., 2015. Electrostatic interactions favor the binding of positive nanoparticles on cells: A reductive theory. Nano Today 10, 677-680. doi:10.1016/j.nantod.2015.07.002 
Franchi, L.P., Manshian, B.B., de Souza, T.A.J., Soenen, S.J., Matsubara, E.Y., Rosolen, J.M., Takahashi, C.S., 2015. Cyto- and genotoxic effects of metallic nanoparticles in untransformed human fibroblast. Toxicol. Vitro Int. J. Publ. Assoc. BIBRA 29, 13191331. doi:10.1016/j.tiv.2015.05.010

Gao, Y., Chen, K., Ma, J.-L., Gao, F., 2014. Cerium oxide nanoparticles in cancer. OncoTargets Ther. 7, 835-840. doi:10.2147/OTT.S62057

Lanone, S., Rogerieux, F., Geys, J., Dupont, A., Maillot-Marechal, E., Boczkowski, J., Lacroix, G., Hoet, P., 2009. Comparative toxicity of 24 manufactured nanoparticles in human alveolar epithelial and macrophage cell lines. Part. Fibre Toxicol. 6, 14. doi:10.1186/1743-8977-6-14

Lin, W., Huang, Y.-W., Zhou, X.-D., Ma, Y., 2006. Toxicity of cerium oxide nanoparticles in human lung cancer cells. Int. J. Toxicol. 25, 451-457. doi:10.1080/10915810600959543

Lord, M.S., Jung, M., Teoh, W.Y., Gunawan, C., Vassie, J.A., Amal, R., Whitelock, J.M., 2012. Cellular uptake and reactive oxygen species modulation of cerium oxide nanoparticles in human monocyte cell line U937. Biomaterials 33, 7915-7924. doi:10.1016/j.biomaterials.2012.07.024

Mittal, S., Pandey, A.K., 2014. Cerium oxide nanoparticles induced toxicity in human lung cells: role of ROS mediated DNA damage and apoptosis. BioMed Res. Int. 2014, 891934. doi:10.1155/2014/891934

Nalabotu, S.K., Kolli, M.B., Triest, W.E., Ma, J.Y., Manne, N.D.P.K., Katta, A., Addagarla, H.S., Rice, K.M., Blough, E.R., 2011. Intratracheal instillation of cerium oxide nanoparticles induces hepatic toxicity in male Sprague-Dawley rats. Int. J. Nanomedicine 6, 2327-2335. doi:10.2147/IJN.S25119

OECD Environment, Health and Safety Publications, Series on the Safety of, Manufactured, Nanomaterials, 2010. ENV/JM/MONO(2010)46 - LIST OF MANUFACTURED 
NANOMATERIALS AND LIST OF ENDPOINTS FOR PHASE ONE OF THE SPONSORSHIP PROGRAMME FOR THE TESTING OF MANUFACTURED NANOMATERIALS: REVISION.

Peng, L., He, X., Zhang, P., Zhang, J., Li, Y., Zhang, J., Ma, Y., Ding, Y., Wu, Z., Chai, Z., Zhang, Z., 2014. Comparative pulmonary toxicity of two ceria nanoparticles with the same primary size. Int. J. Mol. Sci. 15, 6072-6085. doi:10.3390/ijms15046072

Pešić, M., Podolski-Renić, A., Stojković, S., Matović, B., Zmejkoski, D., Kojić, V., Bogdanović, G., Pavićević, A., Mojović, M., Savić, A., Milenković, I., Kalauzi, A., Radotić, K., 2015. Anti-cancer effects of cerium oxide nanoparticles and its intracellular redox activity. Chem. Biol. Interact. 232, 85-93. doi:10.1016/j.cbi.2015.03.013

Poma, A., Ragnelli, A.M., de Lapuente, J., Ramos, D., Borras, M., Aimola, P., Di Gioacchino, M., Santucci, S., De Marzi, L., 2014. In vivo inflammatory effects of ceria nanoparticles on CD-1 mouse: evaluation by hematological, histological, and TEM analysis. J. Immunol. Res. 2014, 361419. doi:10.1155/2014/361419

Pulido-Reyes, G., Rodea-Palomares, I., Das, S., Sakthivel, T.S., Leganes, F., Rosal, R., Seal, S., Fernández-Piñas, F., 2015. Untangling the biological effects of cerium oxide nanoparticles: the role of surface valence states. Sci. Rep. 5, 15613. doi:10.1038/srep15613

Rosenkranz, P., Fernández-Cruz, M.L., Conde, E., Ramírez-Fernández, M.B., Flores, J.C., Fernández, M., Navas, J.M., 2012. Effects of cerium oxide nanoparticles to fish and mammalian cell lines: An assessment of cytotoxicity and methodology. Toxicol. Vitro Int. J. Publ. Assoc. BIBRA 26, 888-896. doi:10.1016/j.tiv.2012.04.019

Schubert, D., Dargusch, R., Raitano, J., Chan, S.-W., 2006. Cerium and yttrium oxide nanoparticles are neuroprotective. Biochem. Biophys. Res. Commun. 342, 86-91. doi:10.1016/j.bbrc.2006.01.129 
Urner, M., Schlicker, A., Z'graggen, B.R., Stepuk, A., Booy, C., Buehler, K.P., Limbach, L., Chmiel, C., Stark, W.J., Beck-Schimmer, B., 2014. Inflammatory response of lung macrophages and epithelial cells after exposure to redox active nanoparticles: effect of solubility and antioxidant treatment. Environ. Sci. Technol. 48, 13960-13968. doi:10.1021/es504011m

Wang, L., Ai, W., Zhai, Y., Li, H., Zhou, K., Chen, H., 2015. Effects of Nano-CeO ${ }_{2}$ with Different Nanocrystal Morphologies on Cytotoxicity in HepG2 Cells. Int. J. Environ. Res. Public. Health 12, 10806-10819. doi:10.3390/ijerph120910806

Xia, T., Kovochich, M., Liong, M., Mädler, L., Gilbert, B., Shi, H., Yeh, J.I., Zink, J.I., Nel, A.E., 2008. Comparison of the mechanism of toxicity of zinc oxide and cerium oxide nanoparticles based on dissolution and oxidative stress properties. ACS Nano 2, 21212134. doi:10.1021/nn800511k 